Acta Universitatis Wratislaviensis No 3799

DOI: $10.19195 / 0524-4544.324 .12$

\author{
EDYTA WŁODARCZYK \\ Uniwersytet Wrocławski \\ edyta.wlodarczyk@uwr.edu.pl
}

\title{
Przejmowanie kościelnych placówek służby zdrowia oraz zakładów opieki społecznej w archidiecezji wrocławskiej w latach 1945-1956
}

Przedmiotem niniejszego artykułu będzie akcja przejmowania kościelnych placówek służby zdrowia oraz zakładów opieki społecznej w okresie powojennym w oparciu o ustawę z dnia 28 października 1948 r. o zakładach opieki społecznej służby zdrowia i planowej gospodarce w służbie zdrowia ${ }^{1}$ oraz dwie uchwały Rady Ministrów z dnia 21 września 1949 r.: w sprawie przejęcia na własność Państwa niektórych szpitali oraz w sprawie przejęcia na własność przez związki samorządu terytorialnego niektórych szpitali utrzymywanych przez stowarzyszenia „Polski Czerwony Krzyż” i „Towarzystwo Ochrony Zdrowia Ludności Żydowskiej” oraz przez kongregacje, związki, stowarzyszenia religijne i fundacje ${ }^{2}$. Uzupełnienie tych aktów prawnych stanowi obwieszczenie prezesa Rady Ministrów z dnia 1 października 1949 r. o sprostowaniu błędów w uchwale Rady Ministrów w sprawie przejęcia na własność przez związki samorządu terytorialnego niektórych szpitali, prostujące błędy w nazewnictwie dwóch związków samorządu terytorialnego ${ }^{3}$.

$* * *$

${ }^{1}$ Dz.U. Nr 55, poz. 434.

2 A. Szymański, Akcja przejmowania szpitali wyznaniowych w oparciu o ustawe z 28 października 1948 r. o zakładach spotecznych stużby zdrowia i planowej gospodarce w stużbie zdrowia, „Studia z Prawa Wyznaniowego” 10, Lublin 2007, s. 281-282.

3 M.P. Nr 68, poz. 884 i 885 ; M.P. Nr 69, poz. 886. 
Podłożem ideologicznym represji wobec instytucji kościelnych, budzących konflikt między państwem a Kościołem, była doktryna marksistowska. Dążono do ateizacji społeczeństwa, co postrzegano jako warunek niezbędny do przeprowadzenia głębokich reform społecznych. Proces ateizacji przez komunistów miał oddziaływać zarówno na jednostkę, jak i na całe instytucje, a jego celem było stworzenie nowego socjalistycznego człowieka całkowicie oderwanego od jakiejkolwiek religii. Praktyka ta nieuchronnie prowadziła do zaostrzania się konfliktu z Kościołem niemalże na wszystkich płaszczyznach życia społecznego, w tym w służbie zdrowia.

Jeden z pierwszych konfliktów w służbie zdrowia powstał zaraz po zakończeniu II wojny światowej i dotyczył asystencji sióstr zakonnych w praktykach spędzania płodu, stosowania zastrzyków antykoncepcyjnych i poronnych, co było sprzeczne z doktryną Kościoła katolickiego. Na skutek tego Episkopat Polski wydał specjalne zarządzenie mające za zadanie ochronę zakonnic pielęgniarek przed czynnościami niezgodnymi z moralnością katolicką i przepisami prawa kościelnego. Zgodnie z tym zarządzeniem we własnych szpitalach i lecznicach zgromadzenia zakonne nie powinny pod żadnym warunkiem dopuszczać, by lekarze przeprowadzali operacje spędzania płodu lub stosowali zastrzyki antykoncepcyjne. W pozostałych placówkach służby zdrowia zakonnice nie powinny w ogóle brać udziału w podobnych czynnościach albo starać się ich nie wykonywać, podając jako argument niezgodność tych praktyk z nauką Kościoła oraz zakazem władz zwierzchnich ${ }^{4}$.

Kolejny konflikt budziła obecność praktyk religijnych w szpitalach prowadzonych przez zgromadzenia zakonne. W takich szpitalach zawsze była kaplica, w której odprawiano msze. Chorym zapewniano opiekę kapelana, który udzielał im sakramentów. Ponadto starano się zachęcać chorych do wspólnej modlitwy oraz do uczestniczenia w obrzędach religijnych ${ }^{5}$.

Państwo, spychając Kościół na margines życia społecznego, dążyło do bycia jedynym decydentem kierującym całym społeczeństwem i wszystkimi gałęziami gospodarki. W kwestii służby zdrowia oczekiwano uznania zasady jednolitego państwowego kierownictwa, twierdząc, że wielość ośrodków dyspozycyjnych blokuje wprowadzenie gospodarki planowej. Konsekwencją tego było wprowadzenie 28 października 1948 r. ustawy o zakładach społecznych służby zdrowia i planowej gospodarce w służbie zdrowia. Na jej podstawie Ministerstwo Zdrowia mogło zaliczyć do społecznych zakładów służby zdrowia zakłady lecznicze utrzymywane przez fundacje, kongregacje, związki i stowarzyszenia religijne, a także zakłady lecznicze innych osób prawnych ${ }^{6}$.

${ }^{4}$ E. Kaczmarek, Dlaczego przeszkadzaly? Polityka władz partyjnych i rządowych wobec żeńskich zgromadzeń zakonnych w Polsce w latach 1945-1956, Warszawa 2007, s. 169.

5 Ibidem.

${ }^{6} \mathrm{Na}$ podstawie art. 13 ustawy z dnia 28 października 1948 r. Rada Ministrów mogła m.in.: „1. uchwalić objęcie zakładu społecznego służby zdrowia w zarząd państwowy lub na własność 
Mimo że ustawa z 28 października 1948 r. nie przejmowała na własność państwa placówek służby zdrowia należących do zgromadzeń zakonnych, to jednak otwierała drogę do przeprowadzenia akcji ich upaństwowienia. Wyjaśnienie w tej sprawie przedstawił Administrator Apostolski Dolnego Śląska, na którego terenie takich placówek było najwięcej, a Minister Zdrowia zarządzeniem z 5 stycznia 1949 r. zaliczył 25 szpitali kongregacyjnych na terenie województwa wrocławskiego do zakładów społecznej służby zdrowia ${ }^{7}$. Zarządzenie to nie upaństwowiło szpitali, a jedynie dawało Ministerstwu Zdrowia nadzór nad nimi, co w praktyce oznaczało prawo do przeprowadzania lustracji, żądania wyjaśnień i sprawozdań oraz wydawania zarządzeń mających na celu usuwanie wątpliwości co do prowadzenia zakładów służby zdrowia w zgodzie z obowiązującymi przepisami.

$\mathrm{W}$ ankietach nadesłanych przez prezydia powiatowych rad narodowych do Wydziału do spraw Wyznań Prezydium Wojewódzkiej Rady Narodowej we Wrocławiu przedstawiano przykłady ,,akcji Kościoła na terenie placówek służby zdrowia", które wykraczały poza obowiązujące przepisy. Do takich działań należało m.in.: namawianie do udziału w nabożeństwach, odmowa wykonywania zabiegów aborcji bądź asystowania przy nich, eksponowanie emblematów religijnych w salach chorych czy przeprowadzanie zbiórek pieniężnych wśród pacjentów ${ }^{8}$.

Państwa, jeżeli utrzymywanie takiego zakładu [...] należało do zadań Państwa, 2. uchwalić przejęcie przez związek samorządu terytorialnego w zarząd lub na własność zakładu społecznego służby zdrowia, jeżeli w innej drodze nie była możliwa prawidłowa realizacja sieci zakładów [...] lub jeżeli właściciel nie był w możności utrzymać zakładu na odpowiednim poziomie, 3. ustalać warunki przejęcia w zarząd lub na własność w powyższych przypadkach”.

${ }^{7}$ E. Kaczmarek, op. cit., s. 170; A. Szymański, Przejmowanie przez władze komunistyczne szpitali wyznaniowych, jako realizacja taktyki ,podcinania skrzydet” Kościoła katolickiego i innych wspólnot religijnych na Ślasku, [w:] A. Szymański, Prawo. Trwanie. Tożsamość. Okruchy historyczno-prawne, Lublin 2016, s. 80; A. Szymański, Akcja przejmowania szpitali wyznaniowych ..., s. 290, wymienia następujące szpitale przejęte przez państwo na omawianym terenie: Szpital św. Elżbiety w Świdnicy (własność sióstr elżbietanek z Wrocławia), Szpital katolicki im. św. Elżbiety w Szklarskiej Porębie (własność Katolickiego Zakładu Dobroczynnego pw. św. Elżbiety we Wrocławiu), Szpital św. Józefa we Wrocławiu (własność sióstr elżbietanek z Wrocławia), Szpital św. Jerzego we Wrocławiu (własność sióstr boromeuszek w Trzebnicy), Szpital Sióstr Elżbietanek we Wrocławiu, Szpital Sióstr Urszulanek we Wrocławiu, Szpital oo. Bonifratrów we Wrocławiu, Szpital Parafii Polskiej Ewangelicko-Augsburskiej „Betezda” we Wrocławiu, Szpital św. Anny we Wrocławiu (własność Fundacji Rycerzy Maltańskich we Wrocławiu), Szpital św. Józefa w Dzierżoniowie (własność sióstr elżbietanek z Wrocławia), Szpital Katolicki w Bielawie (własność Parafii Rzymskokatolickiej w Bielawie), Szpital oo. Bonifratrów w Ząbkowicach Śląskich, Szpital Serca Jezusowego w Środzie (własność Zgromadzenia Sióstr św. Wincentego à Paulo), szpital św. Józefa w Głuchołazach (własność Kongregacji Sióstr Miłosierdzia św. Karola Boromeusza w Trzebnicy), szpital św. Elżbiety w Dusznikach-Zdroju (własność sióstr elżbietanek z Wrocławia), Szpital św. Franciszka w Kłodzku (własność Fundacji Szpitalnej pw. św. Franciszka), szpital św. Elżbiety w Słupcu (własność Fundacji Szpitalnej św. Elżbiety w Słupcu), Szpital Fundacji Kościelnej Wspomożenia NMP w Bystrzycy Kłodzkiej.

${ }^{8}$ M. Kała, Formy administracyjnego zwalczania Kościoła katolickiego na Dolnym Śląsku po II wojnie światowej, [w:] Represje wobec Kościoła katolickiego na Dolnym Ślasku i Opolsz- 
Rok 1949 był czasem, w którym konflikt między państwem a Kościołem dotyczący służby zdrowia osiągnął niespotykaną dotąd skalę. Wynikało to nie tylko z postępującej totalitaryzacji życia w Polsce, ale także z wydarzeń $\mathrm{w}$ innych krajach bloku wschodniego. Władze komunistyczne wiedziały, że wpływy kościelne miały największy zasięg w szkolnictwie pielęgniarskim i szpitalnictwie, w związku z tym jedyne i najsłuszniejsze rozwiązanie widziały w zastosowaniu środków organizacyjnych i administracyjnych ułatwiających ofensywę polityczną i ograniczających bazę materialną i organizacyjną kleru.

Jedną z pierwszych zmian w tym kierunku była zmiana przez władze państwowe programu nauczania $\mathrm{w}$ szkołach pielęgniarskich prowadzonych przez zgromadzenia zakonne. Dla przykładu etykę pielęgniarską wykładaną dotychczas przez księży zastąpiono zasadami i techniką pielęgniarską wykładaną przez osoby świeckie. Ponadto w szpitalach ustanowiono stanowisko wicedyrektorów do spraw politycznych i wychowawczych w celu poprawy stanu upolitycznienia w służbie zdrowia, jak również utworzono komisję przyjęć decydującą o naborze do szkoły pielęgniarskiej. W 1949 r. przystąpiono do masowego szkolenia pielęgniarek na 6-miesięcznych kursach Polskiego Czerwonego Krzyża, by stopniowo zmniejszać personel zakonny w placówkach służby zdrowia ${ }^{9}$. W pierwszej kolejności zwalniano personel zakonny, zajmujący stanowiska administracyjne w szpitalach i innych placówkach służby zdrowia, lub też starano się osoby zakonne przekupić i nakłonić do współpracy ${ }^{10}$. Równolegle, pomimo braku wykwalifikowanych pielęgniarek, przystąpiono do zastępowania zakonnych pielęgniarek dyplomowanych świeckimi. Pełną wymianę personelu zakonnego na świecki zaplanowano dopiero na pierwsze półrocze $1962 \mathrm{r}^{11}$

Największą zaś akcją przeprowadzoną w celu całkowitego wyeliminowania zgromadzeń zakonnych z instytucji służby zdrowia było upaństwowienie lub przejęcie pod zarząd państwowy szpitali ${ }^{12}$. Szczególnie istotne były te szpitale, które stanowiły własność zgromadzeń zakonnych. Ich upaństwowienie było najskuteczniejszym sposobem na pozbycie się całego personelu zakonnego w krót-

czyźnie 1945-1989, red. A. Bogaczewicz, S. Krzyżanowska, „Studia i Materiały”, Wrocław 2004, s. $188-189$.

${ }^{9}$ E. Kaczmarek, op. cit., s. 171.

10 J. Marecki, Stosunki państwo-Kościót w Polsce w okresie stalinowskich represji, [w:] Stosunki państwo-Kościół w Polsce 1944-2010, red. R. Łatka, Kraków 2013, s. 28.

${ }^{11}$ L. Fiejdasz, Rola Wydziału do Spraw Wyznań Prezydium Wojewódzkiej Rady Narodowej w Rzeszowie w laicyzacji stużby zdrowia, „Studia z Prawa Wyznaniowego” 12, Lublin 2009, s. 212 213. „Według dostępnych danych statystycznych w 1960 r. na terenie województwa wrocławskiego w 413 placówkach służby zdrowia zatrudnionych było łącznie 354 zakonnic i zakonników (w tym $327 \mathrm{w}$ szpitalach, $6 \mathrm{w}$ sanatoriach, $16 \mathrm{w}$ ośrodkach zdrowia i $5 \mathrm{w}$ punktach zdrowia). Ogółem w służbie zdrowia pracowało 46 kapelanów oraz 410 zakonnych pielęgniarek i pielęgniarzy. Na 59 szpitali 46 posiadało własnego kapelana, a kolejnych 7 było obsługiwanych przez księży, którzy jednak nie działali w oparciu o wcześniej zawarte umowy" - M. Kała, loc. cit.

${ }^{12}$ E. Kaczmarek, op. cit., s. 172. 
kim czasie. Władze państwowe były zdania, że Kościół w Polsce, dysponujący siecią placówek wychowawczych i szpitali, wykorzystuje je jako narzędzie politycznego okłamywania społeczeństwa oraz przykrywkę dla działalności podziemnych organizacji - i w ten sposób uzasadniały ich przejęcie w ręce państwa lub odpowiednio ukierunkowanych politycznie organizacji społecznych ${ }^{13}$.

Decyzję o upaństwowieniu szpitali podjęto na mocy uchwał Rady Ministrów z 21 września 1949 r. ${ }^{14}$, tłumacząc to tym, że wiele szpitali, zwłaszcza tych znajdujących się na terenie Dolnego Śląska, odmówiło przyjęcia narzuconych przez czynniki partyjne wicedyrektorów. 24 września 1949 r. Minister Administracji Publicznej opracował wzór pisma skierowanego do wojewodów, które zawierało polecenie powołania odpowiedniej liczby komisji zdawczo-odbiorczych wraz $\mathrm{z}$ ustanowieniem ich przewodniczących $\mathrm{w}$ celu przejęcia wymienionych w uchwale Rady Ministrów zakładów leczniczych i sporządzenia protokołów zdawczo-odbiorczych ${ }^{15}$.

Podstawę prawną przejmowania szpitali stanowił art. 13 ust. 1 pkt 1 i 3 ustawy z dnia 28 października 1948 r. o zakładach społecznych służby zdrowia i planowej gospodarce w służbie zdrowia. Ustawa ta uprawniała Radę Ministrów do przejęcia na własność zakładu służby zdrowia, gdy w inny sposób nie była możliwa realizacja sieci zakładów lub gdy właściciel nie był w stanie utrzymać zakładu na odpowiednim poziomie. Oba te przypadki zastosowano w stosunku do szpitali zakonnych w województwie wrocławskim. W odniesieniu do każdego szpitala zakonnego była podejmowana oddzielna uchwała rządu o nieodpłatnym przejęciu na własność państwa ${ }^{16}$. Nad przebiegiem akcji czuwał Departament VI Samorządu Ministerstwa Administracji Publicznej, utrzymując stały kontakt z wojewoda-

13 Instytut Pamięci Narodowej Oddziałowe Biuro Udostępniania i Archiwizacji Dokumentów w Warszawie (IPN Bu), sygn. 01283/1062/Jacket, Protokół — szkody działania kleru katolickiego, brak daty, k. 98; IPN Bu, sygn. 01283/1062/Jacket, pismo „Wroga działalność kleru”, brak daty, k. 158.

${ }^{14}$ M.P. $1949 \mathrm{Nr}$ 68, poz. 884; M.P. $1949 \mathrm{Nr}$ 68, poz. 885.

15 A. Szymański, Akcja przejmowania szpitali wyznaniowych ..., s. 284.

${ }^{16}$ Archiwum Państwowe we Wrocławiu (APW), sygn. 291, pismo Wojewody Wrocławskiego z dnia 2 października 1949 r., k. 183. „Komisja zdawczo-odbiorcza powołana przez ob. Wojewodę Wrocławskiego pismem z dnia 2 października 1949 r. nr 213/tjn/49 zawiadamia, że na podstawie przepisów art. 13 ust. 1 pkt 2, art. 45 ustawy z dnia 28 października 1949 r. o zakładach społecznych służby zdrowia (Dz.U. Nr 56, poz. 434) oraz uchwały Rady Ministrów z dnia 21 września 1949 r., $\mathrm{Nr} 68$, poz. 885, szpital św. Jerzego położony we Wrocławiu przy ul. Wincentego Witosa 22/28, stanowiący własność ss. Boromeuszek w Trzebnicy został w dniu 3 października 1949 r. przejęty na własność Gminy m. Wrocławia. Upoważnionym do działania w imieniu i na rzecz Gminy m. Wrocławia został dotychczasowy Dyrektor Szpitala ob. dr Górny Witold oraz nowomianowany wicedyrektor ob. Grzechowski Władysław. Nominacja z dnia 3 października 1949 r.” — APW sygn. 291, pismo przewodniczącego Komisji do Okręgowej Izby Lekarskiej we Wrocławiu z dnia 3 października 1949 r., k. 177. 
mi oraz poszczególnymi komisjami w terenie, by te, w razie wątpliwości, mogły uzyskiwać dalsze instrukcje oraz pouczenia ${ }^{17}$.

Na podstawie podanych wyżej przepisów władze mogły dokonać zaboru albo poprzez przejęcie na własność państwa lub powiatowego związku samorządu terytorialnego albo poprzez objęcie w zarząd większości zakładów służby zdrowia, dotąd nieupaństwowionych lub nieprzejętych przez samorząd terytorialny.

Jak słusznie zauważył Andrzej Szymański w swojej publikacji Akcja przejmowania szpitali wyznaniowych $w$ oparciu o ustawe z 28 października $1948 \mathrm{r}$. o zakładach spolecznych stużby zdrowia i planowej gospodarce $w$ stużbie zdrowia, art. 31 ust. 1 ustawy z dnia 28 października 1948 r. precyzuje, iż uchwały o przejęciu szpitali „,podejmuje Rada Ministrów na wniosek Ministra Zdrowia, zgłoszony w porozumieniu z Ministrem Skarbu i innymi właściwymi ministrami. Uchwały te wymagają zgody Rady Państwa", jednak w uchwałach tych powoływano się na zgodę Rady Państwa, która została udzielona dopiero 7 dni po ich wydaniu, a więc obie te uchwały zostały wydane niezgodnie $\mathrm{z}$ obowiązującymi procedurami, określonymi w ustawie z 28 października 1948 r. o zakładach społecznych służby zdrowia i planowej gospodarce w służbie zdrowia ${ }^{18}$.

$* * *$

Większość szpitali i placówek służby zdrowia należących do zgromadzeń zakonnych oraz instytucji kościelnych i wyznaniowych została przejęta podczas zorganizowanej akcji przeprowadzonej 3 października 1949 r. Prócz samych wywłaszczeń uciekano się także do zastraszania i nękania kierownictwa szpitali i innych placówek leczniczych. Działania te były wynikiem realizacji przez komunistów planu zepchnięcia Kościoła na margines życia społecznego oraz pozbawienia go możliwości jakiegokolwiek oddziaływania na społeczeństwo.

Zorganizowana w tajemnicy quasi-policyjna akcja miała na celu zaskoczenie nieprzygotowanego „przeciwnika”, by dzięki temu sprawniej przejąć określone placówki służby zdrowia. Procedura przejmowania szpitali kończyła się zatwierdzeniem protokołu zdawczo-odbiorczego przez Ministra Administracji Publicznej, po rozpatrzeniu ewentualnych odwołań byłych właścicieli przez komisje ministerialne. Przeważającą część protokołów zatwierdzono w tym samym dniu, a mianowicie 31 grudnia 1949 r. ${ }^{19}$ Kwestie szczegółowe regulowała zaś, jak już wyżej wspomniano, instrukcja Ministra Administracji Publicznej z dnia 21 wrze-

17 A. Szymański, Akcja przejmowania szpitali wyznaniowych ..., s. 285.

18 Ibidem, s. 284.

19 A. Szymański, Proces likwidacji działalności charytatywnej Kościoła katolickiego w sferze publicznoprawnej w latach 1944-1965. Studium historyczno-prawne, Opole 2010, s. 136. 
śnia 1949 r. w sprawie sporządzania protokołów zdawczo-odbiorczych szpitali przejmowanych na własność związków samorządu terytorialnego.

Ministerstwo Administracji Publicznej oceniło organizację oraz przebieg akcji przejmowania szpitali w sposób pozytywny. Jednak analizując dokumenty znajdujące się m.in. w Archiwum Państwowym we Wrocławiu, można zauważyć szereg nieprawidłowości i działań niezgodnych z prawem. Podczas przebiegu akcji upaństwowienia szpitali dokonano wielu nadużyć, mających znamiona kradzieży. Zgodnie z powołanymi wyżej przepisami i instrukcjami przejęciu powinny podlegać tylko rzeczy ściśle związane $\mathrm{z}$ funkcjonowaniem szpitala. W wielu jednak przypadkach do protokołów zdawczo-odbiorczych wpisywano również przedmioty należące do zakonu. Nierzadko zawłaszczano cały majątek zakonów oraz środki zgromadzone na kontach bankowych bez rozdzielenia na szpital i za$\mathrm{kon}^{20}$, mimo dokładnych rozliczeń w dokumentach księgowych, co było sprzeczne z § 2 obu uchwał z dnia 21 września 1949 r., które nic nie mówiły o możliwości zarekwirowania gotówki, w związku z czym jej zabór stanowił kradzież, czyli przestępstwo kryminalne. Taka sytuacja miała miejsce w przypadku szpitala św. Jerzego we Wrocławiu, prowadzonego przez siostry boromeuszki. Przełożona zakonu, siostra Walburga Grządziel, po przejęciu szpitala przez komisję zdawczo-odbiorczą domagała się zwrotu tych przedmiotów, które nie należały bezpośrednio do szpitala, lecz stanowiły majątek zgromadzenia sióstr boromeuszek:

W związku z przejęciem przez Zarząd Miejski Szpitala św. Jerzego oświadcza, że:

3 pianina znajdujące się na terenie Szpitala, są własnością Kongregacji SS. Boromeuszek w Trzebnicy.

Kwota złotych 10.795 ,- zapisana jako nadwyżka kasowa powstała na skutek niewypłacenia poborów jednej z sióstr zakonnych, zatem kwota ta należy się Kongregacji.

Odnośnie plonów zebranych w gospodarstwie w Widawie oświadczam, że gospodarstwo było własnością Kongregacji, a nie Szpitala i siostry zakonne siały, a więc nam plony się należą ${ }^{21}$.

Przedstawiciele komisji w sprawozdaniu z działalności komisji zdawczo-odbiorczej przejęcie gospodarstwa na rzecz gminy miasta Wrocław thumaczyli ujęciem w budżecie szpitala pozycji dotyczącej przychodu i rozchodu z tego gospodarstwa od dnia 1 października 1949 r. oraz uznali, że wraz z budynkiem pralni stanowi ono integralną część szpitala. Ponadto komisja przejęła dwa budynki przylegające do szpitala, z których jeden był zamieszkiwany przez pracowników w całości, a drugi częściowo. $\mathrm{W}$ drugim budynku dwie kaplice oraz mieszkania zajmowane przez siostry zakonne oraz kapelana nie zostały przejęte. W dalszej części protokołu sprawozdawca stwierdził, że zarówno matka wikaria zgromadzenia sióstr boromeuszek, jak i siostra przełożona nie podpisały protokołu zdawczo-odbiorczego oraz odmówiły złożenia oświadczenia odmownego w formie pisemnej. Protokół został

${ }^{20}$ APW, sygn. 291, pismo Przewodniczącego Komisji do PKO Oddział Wrocław z dnia 4 października 1949 r., k. 181.

${ }^{21}$ APW, sygn. 291, pismo siostry Walburgi Grządziel do Zarządu Miejskiego we Wrocławiu z dnia 14 października 1949 r., k. 175. 
więc podpisany przez wicedyrektora szpitala Witolda Górnego, którego uznano za wykazującego zrozumienie i życzliwość w udzielaniu cennych wskazówek w pracach komisji. Prace komisji zakończyły się w dniu 15 października 1949 r. ${ }^{22}$ Komisja ta podczas swoich prac w piśmie do Pocztowej Kasy Oszczędnościowej prosiła również o zamknięcie konta nr VIII-1070 szpitala św. Jerzego i przysłanie wyciągu bankowego na dzień 3 października. Jednocześnie upoważniała się do dysponowania gotówką zgromadzoną na tym koncie ${ }^{23}$.

W sytuacjach, gdy zakony sprzeciwiały się tego typu działaniom organów władz, uznając je za niezgodne z przepisami prawa, Minister Administracji $\mathrm{Pu}-$ blicznej, zatwierdzając takie protokoły, uznawał zazwyczaj, że znajdujące się w protokole zdawczo-odbiorczym przedmioty stanowią część składową danego szpitala, a więc również podlegają przejęciu ${ }^{24}$. W tej sytuacji odwołania pisane przez przełożonych poszkodowanych zgromadzeń zakonnych, jak również przedstawicieli hierarchii kościelnej, nie odnosiły żadnego skutku ${ }^{25}$.

Domaganie się przez komisje zdawczo-odbiorcze złożenia podpisu przez przełożoną konwentu pod protokołem zdawczo-odbiorczym miało upozorować zgodę właściciela obiektu na zapisy zawarte w protokole. Zdarzały się przypadki, że do podpisywania protokołu zmuszano przełożone niższego szczebla, co oczywiście nie miało znaczenia prawnego, gdyż osoby te nie były upoważnione przez właścicieli obiektów do zastępowania ich w kwestiach majątkowych. One same też w większości przypadków odmawiały złożenia podpisu, jak to miało miejsce w przypadku wyżej opisanego przejęcia szpitala św. Jerzego we Wrocławiu. W tych wypadkach podpisy składali np. świeccy wicedyrektorzy szpitali, którzy także nie mieli w tym kierunku jakichkolwiek uprawnień.

Równocześnie z przejmowaniem szpitali prowadzono akcję rugowania sióstr zakonnych z pracy w szpitalu, zastępując je stopniowo personelem świeckim ${ }^{26}$. Jako wyjaśnienie takiego postępowania podawano tworzenie w szpitalu atmosfery zgodnej z wymogami wolności sumienia i ogólnie przyjętą zasadę świeckości placówek służby zdrowia. W stosunku do zakonnic pracujących w szpitalach prowadzono akcję inwigilacyjną, mającą na celu udowodnienie, że zakonnice te działają wbrew polityce państwa i skłaniają chorych oraz personel świecki do praktyk religijnych, nierzadko wbrew ich woli.

22 APW, sygn. 291, Sprawozdanie z działalności komisji zdawczo-odbiorczej szpitala św. Jerzego we Wrocławiu w czasie od 3 października 1949 r. do 15 października 1949 r., k. 163.

${ }^{23}$ APW, sygn. 291, pismo przewodniczącego Komisji do Okręgowej Izby Lekarskiej we Wrocławiu z dnia 3 października 1949 r., k. 177.

${ }^{24}$ E. Kaczmarek, op. cit., s. 175.

${ }^{25}$ APW, sygn. VI/680, pismo Kongregacji ss. Miłosierdzia św. Karola Boromeusza w Trzebnicy do Urzędu Wojewódzkiego Wrocławskiego Wydziału Społeczno-Politycznego z dnia 13 września 1948 r., k. 156.

${ }^{26}$ APW, sygn. 300, pismo dyrektora szpitala św. Jerzego we Wrocławiu W. Górnego do dyrektora M. Czarneckiego (w miejscu) z dnia 12 lutego 1946 r., k. 21. 
W sprawie zwalnianych ze szpitali zakonnic interweniowały w Urzędzie do spraw Wyznań zarządy poszczególnych zgromadzeń. Skargi te jednak nie zawsze otrzymywały odpowiedź, a jeśli już, to potwierdzały one słuszność podjętych decyzji o zwolnieniu. Na skutek częstych interwencji Episkopatu Polski Ministerstwo Zdrowia zobowiązało się nie zwalniać sióstr zakonnych bez ważnej przyczyny. Pomimo tych ustaleń siostry zakonne nadal były zwalniane ${ }^{27}$. Urząd do spraw Wyznań oraz Ministerstwo Zdrowia wbrew temu, co ustalili z Episkopatem Polski, konsekwentnie dążyli do całkowitego wyeliminowania personelu zakonnego w szpitalach, zastępując go personelem świeckim.

$* * *$

Przejęcia wyznaniowych placówek służby zdrowia na terenie archidiecezji wrocławskiej dokonywano także poza zorganizowaną 3 października 1949 r. akcją. Ponadto niemalże wszystkie przejęcia obciążone były wadami proceduralnymi i prawnymi. Wielu przejęć dokonano jeszcze przed rokiem 1949.

Ciekawy przypadek stanowi sprawa przejęcia szpitala im. Dyherrna w Kożuchowie, należącego do sióstr elżbietanek. $Z$ dokumentów archiwalnych nie wynika, na jakiej podstawie prawnej dokonano jego przejęcia ani czy ostatecznie został zwrócony. Kwestią zasadniczą jest to, że trafił on w ręce Starostwa Powiatowego w Kożuchowie, jeszcze zanim zaczęła obowiązywać ustawa z 28 października 1948 r. Administracja Apostolska Dolnego Śląska w piśmie z dnia 25 kwietnia 1947 r. do Wydziału Społeczno-Politycznego Urzędu Wojewódzkiego Wrocławskiego prosiła o zwrot szpitala im. Dyherrna, gdyż stanowił on własność kościelną. Z dalszej części pisma wynika, że sprawa ta toczyła się już co najmniej od października 1946 r. Administracja Apostolska wysłała wówczas do Starostwa Powiatowego w Kożuchowie dokumenty, które jasno wskazywały, że powyższy obiekt jako fundacja pozostawał pod zarządem Arcybiskupa Wrocławskiego. W odpowiedzi na to pismo Wydział Społeczno-Polityczny we Wrocławiu nakazał Starostwu Powiatowemu w Kożuchowie zbadać stan faktyczny nieruchomości w terminie do 10 maja 1947 r. ${ }^{28}$ Dnia 23 maja 1947 r. Starostwo udzieliło odpowiedzi, iż szpital ten od października 1945 do 31 grudnia 1946 r. był administrowany przez Zarząd Miejski w Kożuchowie, który zainwestował spore środki w jego odnowienie oraz zaopatrzył go w urządzenia szpitalne. Z dniem 1 stycznia 1947 r. szpital został przejęty przez Wydział Powiatowy Kożuchowski ${ }^{29}$. Na wystosowaną przez

27 E. Kaczmarek, op. cit., s. 181.

${ }^{28}$ APW, sygn. VI/685, pismo Urzędu Wojewódzkiego Wrocławskiego Wydziału Społeczno-Politycznego do Starosty Powiatowego w Kożuchowie z dnia 3 maja 1947 r., k. 16.

${ }_{29}$ APW, sygn. VI/685, pismo Starosty Powiatowego w Kożuchowie do Urzędu Wojewódzkiego Wrocławskiego Wydziału Społeczno-Politycznego z dnia 23 maja 1947 r., k. 18. 
Wydział Społeczno-Polityczny we Wrocławiu prośbę o przedstawienie zapisów w księgach katastralnych Starosta Powiatowy w Kożuchowie odpowiedział:

Na podstawie zapisu w księgach katastralnych stwierdzono, że Dyherrn w roku 1869 wybudował niniejszy szpital na rzecz Administracji Apostolskiej. Równocześnie nadmieniam, że księgi hipoteczne zostały na tut[ejszym] terenie przez działania wojenne zupełnie zniszczone, przez co nie można stwierdzić praw własności majątku ${ }^{30}$.

W dalszej części korespondencji Administracja Apostolska w piśmie z 10 lipca 1947 r. napisała do Wydziału Społeczno-Politycznego we Wrocławiu, iż według relacji przełożonej sióstr elżbietanek w Kożuchowie Starostwo Powiatowe w Kożuchowie było skłonne zwrócić szpital Administracji Apostolskiej Dolnego Śląska, a czekało jedynie na decyzję Urzędu Wojewódzkiego ${ }^{31}$. Jednak samo Starostwo Powiatowe zaprzeczyło temu, wyjaśniając, że szpital Dyherrna administrowany był w tym czasie przez Wydział Powiatowy i nie mógł być zwrócony Administracji Apostolskiej do czasu zwolnienia właściwego szpitala powiatowego w Nowej Soli przez wojska armii czerwonej ${ }^{32}$. Z ostatniego dokumentu znajdującego się w archiwum państwowym we Wrocławiu, dotyczącego tego szpitala, wynika jedynie, że szpital ten nie został zwrócony prawowitemu właścicielowi, a Starostwo Powiatowe w Kożuchowie czyniło starania o zatrzymanie go w drodze dobrowolnej umowy dzierżawnej ${ }^{33}$.

W przypadku zaś szpitala św. Jadwigi w Lwówku Śląskim przy ulicy Kościelnej oraz szpitala św. Józefa w Sobótce ${ }^{34}$ starosta powiatowy lwówecki wyjaśniał Urzędowi Parafialnemu Rzymsko-Katolickiemu w Lwówku Śląskim, który starał się o zwrot przejętych przez państwo szpitali, iż z uwagi na fakt, że szpitale te wcześniej stanowiły własność państwa niemieckiego, po II wojnie światowej

${ }^{30}$ APW, sygn. VI/685, pismo Starosty Powiatowego w Kożuchowie do Urzędu Wojewódzkiego Wrocławskiego Wydziału Społeczno-Politycznego z dnia 6 czerwca 1947 r., k. brak.

31 APW, sygn. VI/685, pismo Administracji Apostolskiej Dolnego Śląska do Urzędu Wojewódzkiego Wrocławskiego Wydziału Społeczno-Politycznego z dnia 10 lipca 1947 r., k. 25.

32 APW, sygn. VI/685, pismo Starosty Powiatowego Kożuchowskiego do Urzędu Wojewódzkiego Wrocławskiego Wydziału Społeczno-Politycznego z dnia 29 sierpnia 1947 r., k. 28.

${ }^{33}$ APW, sygn. VI/685, pismo Starosty Powiatowego Kożuchowskiego do Urzędu Wojewódzkiego Wrocławskiego Wydziału Społeczno-Politycznego z dnia 14 lutego 1948 r., k. 30.

${ }^{34}$ Urząd Wojewódzki, Wrocławski Wydział Społeczno-Polityczny w piśmie m.in. do Administracji Apostolskiej Dolnego Śląska z dnia 3 maja 1947 r., prosząc o nadesłanie do wglądu odpisów wyciągów katastralnych potwierdzających prawa własności Kościoła rzymsko-katolickiego do szpitala św. Józefa w Sobótce oraz szpitala św. Jadwigi w Lwówku Śląskim, błędnie podał, iż Sobótka leży w powiecie lwóweckim, mimo że administracyjnie Sobótka od 1946 r., a więc od czasu pierwszego powojennego podziału administracyjnego Polski, należała do powiatu wrocławskiego. Podobny błąd znajdował się w pozostałych pismach dotyczących omawianej sprawy. Stąd też Starosta Powiatowy Lwówecki zajmował się również sprawą szpitala św. Józefa w Sobótce. APW, sygn. VI/666, pismo Urzędu Wojewódzkiego Wydziału Społeczno-Politycznego we Wrocławiu do Administratora Apostolskiego Dolnego Śląska z dnia 3 maja 1947 r., k. 50; APW, sygn. VI/666, pismo Urzędu Wojewódzkiego Wydziału Społeczno-Politycznego we Wrocławiu do Starosty Powiatowego w Lwówku Śląskim z dnia 5 maja 1947 r., k. 51. 
automatycznie przeszły na własność państwa polskiego zgodnie z art. 2 pkt 4 dekretu Rady Ministrów z dnia 8 marca 1946 r. o majątkach opuszczonych i poniemieckich ${ }^{35}$. Oba te szpitale stanowiły własność sióstr boromeuszek i były zarządzane przez nie nawet w okresie wojny ${ }^{36}$. W ten sam sposób Starostwo Powiatowe zajęło szpital św. Jadwigi w Jeleniej Górze, stanowiący własność fundacji kościelnej, a w czasie rewizji zabrano siostrom takie przedmioty, jak wieczne pióra, noże, widelce czy łyżeczki ${ }^{37}$.

Zgodnie natomiast z pismem Wizytatorki Generalnej Sióstr św. Elżbiety w Polsce, siostry M. Jolanty Przybył, według stanu na kwiecień 1947 r. odebrano im następujące nieruchomości:

1) Szpital św. Elżbiety w Środzie Śląskiej, będący własnością zgromadzenia, zajęty przez tamtejsze Starostwo Powiatowe.

2) Szpital św. Józefa w Nowej Soli, własność zgromadzenia, zajęty przez Zarząa Miejski.

3) Szpital św. Jerzego w Legnicy, własność zgromadzenia, zajęty przez wojsko rosyjskie.

4) Dom wypoczynkowy „Fortuna” w Lądku-Zdroju, własność zgromadzenia, zajęty przez wojsko rosyjskie.

5) Dwa domy w Lubiążu, własność zgromadzenia, ul. Wolności 7/8, zajęty przez wojsko rosyjskie.

6) Szpital w Kożuchowie, ul. Szprotawska 19, własność kościelna, zajęty przez Starostwo Powiatowe ${ }^{38}$.

Przejęcia powyższych nieruchomości na terenie archidiecezji wrocławskiej dokonywano przeważnie w oparciu o dekret Rady Ministrów z dnia 8 marca 1946 r. o majątkach opuszczonych i poniemieckich ${ }^{39}$ oraz o dekret z dnia 21 grudnia 1945 r. o publicznej gospodarce lokalami i kontroli najmu ${ }^{40}$, który w art. 23 stanowił, że przepisom o publicznej kontroli najmu nie podlegają m.in. budynki będące własnością osób prawnych prawa publicznego ${ }^{41}$.

\footnotetext{
$* * *$
}

${ }^{35}$ APW, sygn. VI/666, pismo Starosty Powiatowego Lwóweckiego do Urzędu Parafialnego Rzymsko-Katolickiego w Lwówku Śląskim z dnia 14 kwietnia 1947 r., k. 57.

${ }^{36}$ APW, sygn. VI/666, pismo Urzędu Parafialnego Rzymsko-Katolickiego w Lwówku Śląskim do Starosty Powiatowego Lwóweckiego z dnia 15 kwietnia 1947 r., k. 58.

37 APW, sygn. VI/666, pismo Administracji Apostolskiej Dolnego Śląska do Urzędu Wojewódzkiego Wrocławskiego Wydziału Społeczno-Politycznego z dnia 20 kwietnia 1947 r., k. 72.

38 APW, sygn. VI/666, pismo Wizytatorki Generalnej Sióstr Św. Elżbiety w Polsce siostry M. Jolanty Przybył do Administracji Apostolskiej we Wrocławiu z dnia 20 kwietnia 1947 r., k. 75.

39 Dz.U. 1946 Nr 13, poz. 87; APW, sygn. VI/666, pismo Wydziału Społeczno-Politycznego we Wrocławiu do Wydziału Samorządowego (w gmachu) z dnia 18 sierpnia 1947 r., k. brak.

${ }^{40}$ Dz.U. $1946 \mathrm{Nr}$ 4, poz. 27.

${ }^{41}$ APW, sygn. VI/669, pismo Wydziału Społeczno-Politycznego we Wrocławiu do Prezydenta Miasta Wrocławia z dnia 14 stycznia 1947 r., k. 15. 
W 1949 r., podczas prac komisji zdawczo-odbiorczych, powszechny był brak poszanowania dla klauzury zakonnej podczas przejmowania obiektów szpitalnych czy zakładów opieki społecznej ${ }^{42}$. Zdarzały się też przypadki rabunków. Podczas rewizji Zakładu Domu Starców w Mrozowie komisja zabrała rzeczy stanowiące własność kościelną, o zwrot których bezskutecznie w imieniu parafii w Mrozowie starała się Administracja Apostolska Dolnego Śląska ${ }^{43}$.

Problemy z niewłaściwym zakwalifikowaniem zakonnych i szpitalnych składników majątkowych występowały praktycznie we wszystkich przypadkach przejęcia placówek służby zdrowia $\mathrm{w}$ archidiecezji wrocławskiej. Jedną z przyczyn tych nieprawidłowości były z pewnością nieczytelne kryteria kwalifikacji w przywoływanych wyżej uchwałach Rady Ministrów, niezorientowanie władz w realiach funkcjonowania połączonych ze szpitalami domów zakonnych, ale także celowe pozostawienie możliwości szerokiej interpretacji przepisów przez komisje zdawczo-odbiorcze oraz brak odpowiedzialności przy popełnianiu nadużyć. Na terenie archidiecezji wrocławskiej $\mathrm{w}$ wielu przypadkach przy szpitalach istniały jednocześnie domy zakonne danego zgromadzenia, które nie zawsze służyły szpitalowi. Dla komisji nie miało to jednak większego znaczenia i przy upaństwawianiu szpitala zawłaszczano również pozostałe budynki na rzecz samorządu terytorialnego. Były to działania sprzeczne z uchwałami Rady Ministrów z 21 września 1949 r., które w swoim $\S 3$ stanowiły, iż Skarb Państwa lub związki samorządu terytorialnego i gminy miejskie równocześnie z przejęciem na własność szpitali objętych uchwałą przejmują $\mathrm{w}$ bezpłatne użytkowanie nieruchomości używane dotychczas dla potrzeb tych szpitali. W związku z tym, jeśli w danym budynku prócz szpitala znajdowała się również np. kaplica lub klauzura niesłużąca potrzebom tego szpitala, to zajmowanie całego budynku było bezprawne. Tego typu działania komisji zdawczo-odbiorczych dezorganizowały życie konwentu i uniemożliwiały normalne funkcjonowanie, a tym samym zmuszały do całkowitej likwidacji danego zgromadzenia zakonnego.

Z historyczno-prawnego punktu widzenia ciekawy przypadek stanowi upaństwowienie, a następnie zwrot szpitala sióstr boromeuszek w Trzebnicy, będącego, jak to podkreśla Andrzej Szymański, ,prawdopodobnie jedyną w skali kraju

42 „Doszło do wiadomości Administracji Apostolskiej, że Miejski Wydział Zdrowia usiłuje zająć część domu ss. Urszulanek na Karłowicach, przeznaczoną na klauzurę sióstr zakonnych. Zaznaczam, że cały dom ss. Urszulanek na Karłowicach przy al. Kasprowicza 64-66 jest hipoteczną własnością zakonu katolickiego. Przekroczenie klauzury zakonnej, której nietykalność gwarantuje ustawa konstytucyjna bez zgody władz kościelnych jest sprzeczne z obowiązującym na terenie Rzeczypospolitej Polskiej stanem prawnym" - APW, sygn. VI/680, pismo Administracji Apostolskiej Dolnego Ślą̧ska do Zarządu Miejskiego Miasta Wrocławia Wydziału Zdrowia z dnia 19 października 1948 r., k. 236.

43 APW, sygn. VI/680, pismo Administracji Apostolskiej Dolnego Śląska do Urzędu Wojewódzkiego Wrocławskiego Wydziału Społeczno-Politycznego z dnia 6 października 1948 r., k. 229. 
lecznicą, która została przez władze z nie do końca jasnych przyczyn zwrócona zakonowi" 44 .

Domy pomocy społecznej przejmowano trochę inaczej niż szpitale i placówki lecznicze. Jak wykazują dokumenty archiwalne, podczas przejmowania kościelnych zakładów opieki społecznej rzadko przedstawiano podstawy prawne przejęcia, stawiając właścicieli przed faktem dokonanym upaństwowienia. Jeśli nawet przedstawiono jakąś podstawę prawną, to zazwyczaj była ona wadliwa. Takie postępowanie świadczy wyraźnie o tym, że ówczesne władze państwowe czuły się zupełnie bezkarne w dążeniu do jak największego ograniczenia wpływów kościelnych w opiece społecznej ${ }^{45}$. Z relacji administratora parafii w Mrozowie ks. Bronisława Kaczanowskiego oraz siostry przełożonej Pryscyliany Kondli jasno wynika brak poszanowania przepisów prawa przez władze państwowe:

W dniu 1 października br. otrzymałem pismo ze Starostwa Powiatowego w Środzie Śląskiej z datą 16 września 1948 r. z poleceniem wydania z Zakładu Domu Starców św. Bernarda w Mrozowie urządzeń przedszkola miejscowemu kierownikowi Szkoły Powszechnej ob. Barańskiemu. [...] następnego dnia w godzinach popołudniowych zajechało auto ze Starostwa Środzkiego celem obejrzenia mebli [...]. Inspekcja skończyła się zabraniem urządzeń przedszkola przy pomocy kierownika miejscowej Szkoły Powszechnej ob. Barańskiego i Gorlasa, lekarza Czerwonego Krzyża bez porozumienia się z Przełożoną Domu siostrą Kondla, mieszkającą w zakładzie św. Karola Boromeusza w Mrozowie, jak również bez zezwolenia miejscowego administratora ks. Bronisława Kaczanowskiego [...]. W poniedziałek, dnia 4 bm. w godzinach przedpołudniowych zajechał autem szef Wydziału Polityczno-Wych. w Środzie Śl. ob. Legenza Stanisław, który przy pomocy urzędników gminy Mrozów przeprowadził rewizję w całym domu starców i zabrał ze strychu

${ }^{44}$ A. Szymański, Proces likwidacji działalności charytatywnej Kościoła katolickiego..., s. 147. „Na podstawie zebranych informacji i opinii minister administracji publicznej B. Wolski wydał w dniu 18 października 1949 r. zarządzenie o dokonaniu zwrotu szpitala w Trzebnicy dawnemu właścicielowi, czyli zgromadzeniu sióstr boromeuszek. Oficjalnym uzasadnieniem owego niecodziennego kroku była »niemożność rozdziału urządzeń gospodarczych szpitala i klasztoru«. Tego samego dnia Kongregacja została powiadomiona o tej decyzji pismem Ministerstwa Administracji Publicznej. Kolejne pismo w tej sprawie siostry otrzymały 25 października 1949 r. z Wydziału Powiatowego w Trzebnicy, które oprócz potwierdzenia wcześniejszych informacji o zaniechaniu przejęcia lecznicy, zawiera natychmiastową dymisję świeżo ustanowionego przez władze wicedyrektora szpitala sióstr boromeuszek, Władysława Gelecińskiego. 30 października 1949 r. komisja do przejęcia Szpitala św. Jadwigi w Trzebnicy dokonała protokolarnego przekazania z powrotem prawowitym właścicielkom zajętych funduszów (146 114,00 zł w gotówce i 1432448 zł na kontach bankowych)" — A. Szymański, Przejmowanie przez władze komunistyczne szpitali wyznaniowych..., loc. cit.

45 „dnia 18 lipca b.r. do domu ss. Boromeuszek w Krzewinie/Grodowice/pow. Zgorzelec, przybyła komisja z tutejszego Starostwa, celem przejęcia tego domu na rzecz R.T.P.D. W domu swym ss. Boromeuszki prowadziły poprzednio szpital, a obecnie prowadzą Dom Dziecka; mieści się tam w tej chwili 45 dzieci. Komisja starościńska wymogła na Siostrze Przełożonej, nieznającej dobrze języka polskiego, podpisanie protokołu zdawczo-odbiorczego" — APW, sygn. VI/680, odpis pisma Katolickiego Urzędu Parafialnego w Zgorzelcu do Kurii Administracji Apostolskiej we Wrocławiu z dnia 20 lipca 1948 r., k. 142. 
rzeczy następujące: przybory kuchenne, pierzyny, materace, żarówki, aparaty do dezynfekcji i do elektryzacji oraz kosze z bielizną ${ }^{46}$.

Inną z przyczyn upaństwowienia kościelnych zakładów opieki społecznej była również odmowa z ich strony podjęcia współpracy z nieuznawanym przez Kościół Zrzeszeniem Katolików Caritas. Dla przykładu, budynek Caritasu w Kamiennej Górze postanowiono przejąć z uwagi na niedopełnienie formalności polegających na złożeniu statutów wszystkich oddziałów stosownie do rozporządzenia Rady Ministrów z dnia 2 października 1947 r. w sprawie uchylenia rozporządzenia Rady Ministrów z dnia 28 stycznia 1934 r. o stowarzyszeniach służących katolickim celom religijnym i wyznaniowym ${ }^{47}$ oraz art. 41 rozporządzenia Prezydenta Rzeczypospolitej Polskiej z dnia 27 października 1932 r. — Prawo o stowarzyszeniach ${ }^{48}$.

Warto zauważyć, że zakony nie były informowane o możliwości wniesienia odwołań, nie doręczano im kopii protokołów zdawczo-odbiorczych, przekraczano terminy przewidziane przez prawo na rozpatrywanie protestów, zażaleń i odwołań. Standardem było nieodpowiadanie na pisma kierowane przez podmioty kościelne do ministerstw bądź innych urzędów. Uniemożliwiało to stronie odwołującej się prowadzenie jakichkolwiek dalszych działań urzędowych ${ }^{49}$.

$* * *$

Dzięki przepisom ustawy z dnia 28 października 1948 r. władze partyjno-państwowe właściwie zakończyły prowadzoną na dużą skalę charytatywną działalność zakonów rzymskokatolickich w zakresie szpitalnictwa. Na podstawie $\S 2$ obu uchwał Rady Ministrów z dnia 21 września 1949 r. na własność państwa i związków samorządu terytorialnego i gmin miejskich przeszły nieodpłatnie ruchomości, użytkowane

${ }^{46}$ APW, sygn. VI/680, pismo administratora parafii w Mrozowie ks. Bronisława Kaczanowskiego oraz siostry przełożonej Pryscyliany Kondli do Administracji Apostolskiej we Wrocławiu z dnia 5 października 1948 r., k. 230.

47 Dz.U. Nr 65, poz. 395.

48 Dz.U. Nr 94, poz. 808; APW, sygn. VI/241, pismo Starosty Powiatowego Kamiennogórskiego do Urzędu Wojewódzkiego Wydziału Społeczno-Politycznego we Wrocławiu z dnia 15 listopada 1948 r., k. 140.

${ }^{49}$ APW, sygn. VI/669, pismo Przełożonej Prowincjonalnej Dolnośląskiej Prowincji SS. Św. Jadwigi „Domu św. Jadwigi” do Urzędu Wojewódzkiego Wrocławskiego Wydziału Samorządowego we Wrocławiu z dnia 25 listopada 1946 r., k. 12; APW, sygn. VI/669, pismo Przełożonej Prowincjonalnej Dolnośląskiej Prowincji SS. Św. Jadwigi „Domu św. Jadwigi” do Urzędu Wojewódzkiego Wrocławskiego Wydziału Samorządowego we Wrocławiu z dnia 25 listopada 1946 r., k. 12; APW, sygn. VI/669, pismo Administracji Apostolskiej Dolnego Śląska do Prezydenta Miasta Wrocławia z dnia 9 grudnia 1946 r., k. 13; A. Szymański, Proces likwidacji działalności charytatywnej Kościoła katolickiego..., s. 183-184. 
na potrzeby upaństwowionych szpitali, stanowiące własność zgromadzenia, związku religijnego, stowarzyszenia czy fundacji, której szpital przejęto. Komisje zdawczo-odbiorcze, prócz przedmiotów potrzebnych bezpośrednio do utrzymania i prowadzenia szpitala, przejmowały również przedmioty należące do instytucji kościelnych zakonnych, jak również gotówkę czy przedmioty osobiste. Świadczy to o totalnym braku poszanowania prawa, a także stworzonej przez prawodawcę możliwości szerokiej interpretacji przepisów i braku konsekwencji w przypadku nadużyć.

Obie uchwały Rady Ministrów z dnia 21 września 1949 r. stanowily, że nieruchomości użytkowane do tej pory jako szpitale przechodzą w bezpłatne użytkowanie nowych właścicieli — Skarbu Państwa lub związków samorządu terytorialnego i gmin miejskich, co w rezultacie oznaczało całkowite pozbawienie dotychczasowego właściciela możliwości zarządzania swoją rzeczą oraz prawa do odszkodowania.

Upaństwowienie kościelnych i zakonnych placówek służby zdrowia oraz zakładów opieki społecznej było znacznym ograniczeniem ich źródeł dochodów, a także zmniejszeniem wpływów zgromadzeń zakonnych na społeczeństwo, co było celowym zamierzeniem władz państwowych. Porozumienie między rządem a Episkopatem Polski zawarte w październiku 1956 r. nie przyniosło żadnych zmian w tym zakresie i zgromadzenia zakonne w odpowiedzi na ich odwołania od postępowania władz nadal były informowane, że wszystko przebiegło zgodnie z obowiązującym porządkiem prawnym.

W każdym z przypadków przejęcia kościelnych placówek służby zdrowia oraz zakładów opieki społecznej zauważalne było instrumentalne traktowanie przepisów prawa przez władze szczebla zarówno lokalnego, jak i centralnego. Decyzje likwidacyjne podejmowano z przyczyn politycznych lub utylitarnych. Działano na podstawie obowiązujących przepisów prawnych, które jednak stosowano w sposób nieadekwatny do stanu faktycznego. Szkodziło to lokalnym społecznościom, osobom zatrudnionym w przejmowanych placówkach, a przede wszystkim podopiecznym instytucji opiekuńczych prowadzonych przez instytucje wyznaniowe.

\title{
Bibliografia
}

\author{
Archiwalia \\ Instytut Pamięci Narodowej \\ Oddziałowe Biuro Udostępniania i Archiwizacji Dokumentów \\ w Warszawie \\ IPN Bu, sygn. 01283/1062/Jacket: Aktotwórca: Ministerstwo Spraw Wewnętrznych. Tytuł teczki: \\ Zakony męskie i żeńskie w Polsce — kontrwywiadowcza charakterystyka zakonów, dane \\ statystyczne, rozpracowania wrogiej działalności kleru.
}




\section{Archiwum Państwowe we Wrocławiu}

APW, sygn. 291: Aktotwórca: Zarząd Miejski we Wrocławiu Wydział Zdrowia z lat 1945-1950. Tytuł teczki: Protokół zdawczo-odbiorczy Szpitala św. Jerzego za rok 1949 od nr 1 do nr 184. APW, sygn. 300, Aktotwórca: Zarząd Miejski we Wrocławiu Wydział Zdrowia z lat 1945-1950. Tytuł teczki: Sprawozdania szpitala św. Jerzego 1945-1946.

APW, sygn. VI/241, Aktotwórca: Urząd Wojewódzki Wrocławski (1945-1950) Wydział Społeczno-Polityczny I Oddział Spraw Społecznych i Politycznych. Tytuł teczki: Różne sprawy stowarzyszeń.

APW, sygn. VI/666, Aktotwórca: Urząd Wojewódzki Wrocławski (1945-1950) Wydział Społeczno-Polityczny II Oddział Wyznaniowy. Tytuł teczki: Różne sprawy kościelne rzym.-kat. 1947.

APW, sygn. VI/669, Aktotwórca: Urząd Wojewódzki Wrocławski (1945-1950) Wydział Społeczno-Polityczny II Oddział Wyznaniowy. Tytuł teczki: Sprawy wyznań katolickich. Przydział kościołów ewangelickich parafiom katolickim 1947.

APW, sygn. VI/680, Aktotwórca: Urząd Wojewódzki Wrocławski (1945-1950) Wydział Społeczno-Polityczny II Oddział Wyznaniowy. Tytuł teczki: Różne sprawy Kościoła RzymskoKatolickiego 1948.

APW, sygn. VI/685, Aktotwórca: Urząd Wojewódzki Wrocławski (1945-1950) Wydział Społeczno-Polityczny II Oddział Wyznaniowy. Tytuł teczki: Sprawy majątkowe gmin chrześcijańskich — niekatolickich.

\section{Akty prawne}

Rozporządzenie Prezydenta Rzeczypospolitej z dnia 27 października 1932 r. — Prawo o stowarzyszeniach, Dz.U. $1932 \mathrm{Nr}$ 94, poz. 808.

Dekret z dnia 21 grudnia 1945 r. o publicznej gospodarce lokalami i kontroli najmu, Dz.U. 1946 $\mathrm{Nr}$ 4, poz. 27.

Dekret z dnia 8 marca 1946 r. o majątkach opuszczonych i poniemieckich, Dz.U. 1946 Nr 13, poz. 87.

Rozporządzenie Rady Ministrów z dnia 2 października 1947 r. w sprawie uchylenia rozporządzenia Rady Ministrów z dnia 28 stycznia 1934 r. o stowarzyszeniach służących katolickim celom religijnym i wyznaniowym, Dz.U. 1947 Nr 65, poz. 395.

Ustawa z dnia 28 października 1948 r. o zakładach służby zdrowia i planowej gospodarce w służbie zdrowia, Dz.U. 1948 Nr 55, poz. 434.

Uchwała Rady Ministrów z dnia 21 września 1949 r. w sprawie przejęcia na własność Państwa niektórych szpitali, M.P. 1949 Nr 68, poz. 884.

Uchwała Rady Ministrów z dnia 21 września 1949 r. w sprawie przejęcia na własność przez związki samorządu terytorialnego niektórych szpitali utrzymywanych przez stowarzyszenia: „Polski Czerwony Krzyż” i „Towarzystwo Ochrony Zdrowia Ludności Żydowskiej” oraz przez kongregacje, związki, stowarzyszenia religijne i fundacje, M.P. $1949 \mathrm{Nr}$ 68, poz. 885.

Obwieszczenie Prezesa Rady Ministrów z dnia 1 października 1949 r. o sprostowaniu błędów w uchwale Rady Ministrów w sprawie przejścia na własność przez związki samorządu terytorialnego niektórych szpitali M.P. $1949 \mathrm{Nr}$ 69, poz. 886.

\section{Literatura}

Fiejdasz L., Rola Wydziału do Spraw Wyznań Prezydium Wojewódzkiej Rady Narodowej w Rzeszowie w laicyzacji stużby zdrowia, „Studia z Prawa Wyznaniowego” 12, Lublin 2009. 
Kaczmarek E., Dlaczego przeszkadzaty? Polityka władz partyjnych i rzadowych wobec żeńskich zgromadzeń zakonnych w Polsce w latach 1945-1956, Warszawa 2007.

Kała M., Formy administracyjnego zwalczania Kościoła katolickiego na Dolnym Śląsku po II wojnie światowej, [w:] Represje wobec Kościoła katolickiego na Dolnym Ślasku i Opolszczyźnie 1945-1989, red. A. Bogaczewicz, S. Krzyżanowska, „Studia i materiały”, Wrocław 2004.

Marecki J., Stosunki państwo-Kościół w Polsce w okresie stalinowskich represji, [w:] Stosunki państwo-Kościót w Polsce 1944-2010, red. R. Łatka, Kraków 2013.

Szymański A., Akcja przejmowania szpitali wyznaniowych w oparciu o ustawę z 28 października 1948 r. o zaktadach społecznych stużby zdrowia i planowej gospodarce w stużbie zdrowia, „Studia z Prawa Wyznaniowego" 10, Lublin 2007.

Szymański A., Proces likwidacji działalności charytatywnej Kościoła katolickiego w sferze publicznoprawnej w latach 1944-1965. Studium historyczno-prawne, Opole 2010.

Szymański A., Przejmowanie przez władze komunistyczne szpitali wyznaniowych, jako realizacja taktyki ,podcinania skrzydet” Kościoła katolickiego i innych wspólnot religijnych na Śląsku, [w:] A. Szymański, Prawo. Trwanie. Tożsamość. Okruchy historyczno-prawne, Lublin 2016.

\section{The take-over of the Church's healthcare centres and nursing homes in the Archdiocese of Wrocław in 1945-1956}

\section{Summary}

The article examines the take-over of the Church's healthcare centres and nursing homes in 19451956, a process based on the Act of 28 October 1948 on healthcare centres, nursing homes and planned economy in health service. Repressions against Church institutions, leading to a conflict between the state and the Church, stemmed from the ideology based on the Marxist doctrine seeking to make society atheist as a prerequisite to carry out profound social reforms. The practice inevitably exacerbated the conflict with the Church in almost all areas of society's life, including health service. The year 1949 was a time in which the conflict between the state and the Church over health service reached an unprecedented scale. The communist authorities knew that the Church's influence was at its most extensive in nurse training and hospitals, and believed that the only and the best solution was to introduce organisational and administrative measures facilitating political offensive and limiting the clergy's material and organisational base. The strongest measure aimed at completely eliminating religious orders from health service institutions was the nationalisation or take-over of hospitals by the state.

Keywords: health service, nationalisation of hospitals, Archdiocese of Wrocław, nursing homes, Catholic Church, nuns

\section{Die Übernahme der kirchlichen Gesundheits- und Wohlfahrtseinrichtungen im Erzbistum Breslau in den Jahren 1945-1956}

\section{Zusammenfassung}

Gegenstand des Artikels ist die organisierte Übernahme der kirchlichen Gesundheitseinrichtungen und Wohlfahrtseinrichtungen in den Jahren 1945-1956 aufgrund des Gesetzes vom 28. Oktober 1948 über die Wohlfahrtseinrichtungen des öffentlichen Gesundheitswesens und die 
Planwirtschaft im Gesundheitswesen. Die Repressionen gegen die kirchlichen Institutionen, die zum Konflikt zwischen Staat und Kirche führten, waren ideologischer Natur und basierten auf marxistischer Doktrin, die die Atheisierung als notwendige Bedingung zur Durchführung tiefer sozialer Reformen der Gesellschaft anstrebte. Diese Praktik führte unvermeidlich zur Verschärfung des Konfliktes mit der Kirche fast auf allen Ebenen des sozialen Lebens, darunter auch im Gesundheitswesen. Im Jahr 1949 erreichte der Konflikt zwischen Staat und Kirche bezogen auf das Gesundheitswesen eine bisher nicht bekannte Stärke. Die kommunistischen Behörden wussten, dass die kirchlichen Einflüsse im Bereich der Fachschulen für Krankenpflege und im Krankenhauswesen am stärksten waren, in organisatorischen und administrativen Mitteln, die die politische Offensive erleichtern und die materielle und organisatorische Basis des Klerus einschränken sollten, sahen sie daher die einzige und richtigste Lösung. Die größte Aktion, Orden aus den Institutionen des Gesundheitswesens zu eliminieren, war die Verstaatlichung bzw. die Übernahme der Krankenhäuser in die staatliche Verwaltung.

Schlüsselworte: Gesundheitswesen, Verstaatlichung der Krankenhäuser, Erzbistum Breslau, Wohlfahrtseinrichtungen, katholische Kirche, Ordensschwestern 